\title{
CHOLESTEROL BIOSYNTHESIS. STUDIES RELATED TO THE METABOLIC ROLE OF SQUALENE ${ }^{1}$
}

\author{
By MAXWELL L. EIDINOFF, JOSEPH E. KNOLL, BENJAMIN J. MARANO, \\ ELLING KVAMME, 2 ROBERT S. ROSENFELD, AND LEON HELLMAN
}

\author{
(From the Divisions of Biophysics and of Steroid Biochemistry, Sloan-Kettering Institute for \\ Cancer Research, Memorial Center, New York, N. Y.)
}

(Submitted for publication December 19, 1957; accepted January 30, 1958)

Following the demonstration by Langdon and Bloch that squalene is efficiently converted to cholesterol in the tissues of the mouse, there has been considerable experimental activity relating to the role of this compound in cholesterol biosynthesis (1-5). In a study of several aspects of this problem in man, it was found in this laboratory that squalene in human sebum was labeled with radiocarbon following oral administration of acetate containing this isotope (6). Using tritium as an isotopic label, a hydrocarbon fraction containing squalene with high specific activity has been prepared and demonstrated to be a cholesterol precursor in the mouse, and to a significant extent, in the human. In addition, the extent of conversion of squalene along metabolic pathways leading to respiratory carbon dioxide and lipid fatty acids was investigated in the mouse using squalene labeled with radiocarbon.

\section{MATERIALS AND METHODS}

Tritium and radiocarbon assay. All tritium assays were made by internal gas phase counting of the hydrogen gas obtained by combustion of the organic compound and complete conversion of the resulting water to hydrogen gas over powdered zinc. The hydrogen gas (admixed with methane to a total pressure of $70 \mathrm{~cm}$. $\mathrm{Hg}$ ) was counted in the upper portion of the proportional region (7). Radiocarbon assays were made by gas-flow windowless counting in the Geiger-Müller region. In the case of samples of respiratory carbon dioxide with low activity (Tables IV and V), the more sensitive internal gas counting procedures described elsewhere were used $(8,9)$.

Preparation of hydrocarbon fractions containing squalene- $T$ and assay of total radioactivity. The reaction mixture consisted of $5.0 \mathrm{ml}$. redistilled squalene (Distil-

${ }^{1}$ This investigation was carried out under contract AT(30-1)-910 with the United States Atomic Energy Commission and supported in part by grants from the National Cancer Institute (C-440) and National Heart Institute, United States Public Health Service.

2 Present address: Ullevål Hospital, Central Laboratory, Oslo, Norway. lation Products Industries), $5.0 \mathrm{ml}$. water containing tritium (specific activity, $1 \mathrm{mc}$. per $\mathrm{mM}$ ), $0.14 \mathrm{Gm}$. KOH and $1.0 \mathrm{Gm}$. powdered platinum catalyst, prepared by the reduction of platinum oxide with ordinary hydrogen gas. After removal of air, the glass ampul containing the reagents was sealed and shaken at $135^{\circ} \mathrm{C}$. for 27 hours. In order to remove tritium in relatively labile positions and eliminate contaminating fats, the product was treated with aqueous alcoholic $\mathrm{KOH}$ under reflux conditions in a nitrogen atmosphere for four hours, then cooled and extracted with petroleum ether. The latter solution was concentrated and chromatographed on alumina. The hydrocarbon fraction, which was eluted from the column with petroleum ether $\left(60^{\circ}\right.$ C. $)$, contained over 99.8 per cent of the tritium activity. The product was stored as a dilute solution in petroleum ether at refrigerator temperatures in order to minimize oxidation. This product (Sample I, the hydrocarbon fraction containing squalene- $T$ ) was used in the experiments described in Tables II and III. The specific activity, based on the hexahydrochloride derivative, was $0.5 \mu \mathrm{c}$. per mg. squalene. A second tritium-containing hydrocarbon fraction (Sample II) was prepared from Sample I via the thiourea adduct (10). One Gm. of Sample I, admixed with an equal weight of redistilled natural squalene, was shaken with $38 \mathrm{ml}$. of a saturated solution of thiourea in methanol. The crystalline adduct was allowed to precipitate at refrigerator temperature. After filtering and washing with iso-octane, the precipitate was then decomposed with boiling water. The squalene was extracted with petroleum ether, which was then dried over sodium sulfate and allowed to percolate through an alumina-packed column in order to remove oxygen-containing impurities. The total tritium activity per $\mathrm{ml}$. of Samples I and II was measured by adding $0.10 \mathrm{ml}$. of a known dilution of these samples to $20 \mathrm{mg}$. cholesterol in a porcelain combustion boat. The boat was inserted into the combustion tube immediately in order to eliminate loss of squalene by surface film effects during solvent evaporation. After removal of the solvent under reduced pressure, the residue in the boat was combusted in the usual manner. The total voume of hydrogen gas corresponded to at least 99 per cent of the hydrogen content of the sample in the boat. A portion of this gas was then counted.

Determination of percentage of total activity present as squalene (Table I). In the case of Sample I, the assay was based on the specific activity of the squalene hexahydrochloride (M. P., $109^{\circ}$ to $20^{\circ} \mathrm{C}$.) prepared from a known dilution with redistilled natural squalene by the 
TABLE I

Assay of hydrocarbon fraction containing squalene- $T$

\begin{tabular}{|c|c|c|c|}
\hline Sample & $\begin{array}{c}\text { Treatment } \\
\text { following } \\
\text { exchange reaction }\end{array}$ & $\begin{array}{c}\text { Squalene } \\
\text { derivative }\end{array}$ & $\begin{array}{l}\text { Percentage } \\
\text { of total } \\
\text { activity } \\
\text { as squalene }\end{array}$ \\
\hline I & $\begin{array}{l}\text { Saponification and } \\
\text { extraction }\end{array}$ & $\begin{array}{l}\text { Mixed hexahydro- } \\
\text { chlorides }\end{array}$ & $55 \pm 4$ \\
\hline \multirow[t]{3}{*}{ II } & \multirow{3}{*}{$\begin{array}{l}\text { I was purified via } \\
\text { thiourea adduct, } \\
\text { followed by regen- } \\
\text { eration and chro- } \\
\text { matography over } \\
\text { alumina }\end{array}$} & $\begin{array}{l}\text { Mixed hexahydro- } \\
\text { chlorides }\end{array}$ & $68 \pm 4$ \\
\hline & & $\begin{array}{l}112^{\circ} \text { melting point } \\
\text { hexahydro- } \\
\text { chloride }\end{array}$ & $56 \pm 3$ \\
\hline & & Dodecabromide & $61 \pm 1$ \\
\hline
\end{tabular}

method of MacKenna, Wheatley, and Wormall (11). In the case of Sample II, assay was based on the specific activities of the mixed hydrochlorides, the 111 to $112^{\circ} \mathrm{C}$. low melting isomer and the dodecabromide prepared as described by MacKenna and co-workers (11). Analysis for dodecabromide: $\mathrm{C}, 26.17 ; \mathrm{H}, 3.71 ; \mathrm{Br}, 70.2$. Calculated: $\mathrm{C}, 26.3 ; \mathrm{H}, 3.74 ; \mathrm{Br}, 70.0$. The results are presented in Table I. On the basis of these derivatives, respectively, the percentage of the total tritium content present as squalene was calculated to be 68,56 and 61 . The remainder of the tritium activity may be present in compounds formed from squalene during the exchange treatment as a result of double bond shifts and other types of isomerization. Evidence for this was obtained from infra-red absorption measurements. The infra-red spectrum of the squalene- $T$ prepared by catalytic exchange was measured using a Perkin-Elmer double beam spectrophotometer. The absorption was very similar to that for redistilled commercial squalene. At $11.29 \mu$, the tritiated product had a larger percentage absorption relative to the commercial product. An enhanced absorption close to this wavelength had been observed by Dauben and Bradlow (12), and Tomkins, Chaikoff, Dauben, Bradlow, and Srere (13) for squalene regenerated from the hexahydrochloride and for synthetic squalene- $C^{14}$. These authors concluded that isomeric forms of squalene, different with respect to double bond positions, were responsible for the absorption at this wavelength.

Animal experiments using squalene-T. In Experiments 1 to 4 and 6 (Table III), an aliquot of squalene-T containing about $30 \mathrm{mg}$. of squalene and an activity of $3 \times$ $10^{7} \mathrm{dpm}$ was mixed with ground Purina Chow and the solvent was removed in a nitrogen stream. The animal was sacrificed 24 hours after the sample was consumed. In Experiment 5, an emulsion of squalene in isotonic saline was prepared by adding water to an equal volume of acetone containing the squalene- $T$. The acetone was removed by repeated addition of water and evaporation to the original volume. This emulsion was injected into the tail vein and the animal was sacrificed after 24 hours. The mouse liver was homogenized and deproteinized with acetone-alcohol $(1: 1)$. An aliquot was removed for cholesterol analysis and the remainder saponified with alcoholic $\mathrm{KOH}$. Following the addition of carrier cholesterol (about $400 \mathrm{mg}$.) the combined dried ether extracts were concentrated to a small volume. This was chromatographed on alumina and the fractions were eluted with petroleum ether followed by increasing concentrations of benzene. The 100 per cent benzene fraction contained almost all the cholesterol. This was converted to the dibromide, which was debrominated by sodium iodide in ethanol-benzene $(14,15)$. The cholesterol was recrystallized 2 times from acetone and melted at 148 to $149^{\circ} \mathrm{C}$

Administration of hydrocarbon fraction containing squalene-T in the human (Table II). Petroleum ether was distilled under nitrogen from a solution containing $150 \mathrm{mg}$. squalene and having an activity of $1.5 \times 10^{8} \mathrm{dpm}$ (assayed as squalene) or $2.7 \times 10^{8} \mathrm{dpm}$ total tritium activity. The nonvolatile residue was dissolved in $10 \mathrm{ml}$. sesame oil and homogenized in $100 \mathrm{ml}$. chocolate milk. This was administered to a 59 year old male, weighing $75 \mathrm{Kg}$. and of limited life expectancy. The subject had cancer of the prostate and at the time of the experiment was considered to be in good nutritional status. The plasma cholesterol determinations were carried out by a modification of the Sperry-Webb procedure (16).

Preparation of squalene- $C^{14}$. Acetate- $2-C^{14}(500 \mu$ c., $0.5 \mathrm{mM}$ ) was administered intraperitoneally to a dog that had ingested $20 \mathrm{Gm}$. natural squalene prior to the experiment. After 40 minutes the animal was sacrificed. The hydrocarbons present in the nonsaponifiable fraction of the liver were obtained by the procedure of Langdon and Bloch (17). Approximately 0.1 per cent of the administered radiocarbon was present in this hydrocarbon eluate. The radiocarbon activity per $\mathrm{ml}$. of the hydrocarbon fraction obtained from the dog liver was measured by gas phase counting of the carbon dioxide from the oxidation of an aliquot (containing a known excess of natural squalene), using the Van Slyke-Folch combustion mixture (18). Another aliquot was mixed with a known excess of squalene, the hexahydrochloride prepared and the specific activity determined by gas phase counting. On this basis, it was found that substantially all the radiocarbon activity was present as squalene (squalene activity/total activity: $1.05 \pm 0.04$ ). A lower

TABLE II

Conversion of hydrocarbon fraction containing squalene- $T$ to cholesterol and fatty acid in the human

\begin{tabular}{ccc}
\hline \hline $\begin{array}{c}\text { Time after } \\
\text { administration } \\
(\text { hrs. })\end{array}$ & $\begin{array}{c}\text { Specific activity } \\
\text { of plasma-free } \\
\text { cholesterol } \\
(d p m / m g .)\end{array}$ & $\begin{array}{c}\text { Specific activity } \\
\text { of fatty acids in } \\
\text { blood lipids } \\
(d p m / m g .)\end{array}$ \\
\hline 1 & 18 & \\
3 & 145 & 106 \\
7 & 2,710 & 156 \\
21 & 4,760 & 53 \\
25 & 4,240 & \\
43 & 3,720 & \\
79 & 2,980 & \\
\hline
\end{tabular}


limit to the specific activity of the squalene in the hydrocarbon fraction was established by determining the amount of squalene per unit volume of solution. This quantity was too small to assay accurately by chemical methods. Consequently, the infra-red spectrum was measured in carbon disulfide solution using a PerkinElmer double beam spectrophotometer and compared with spectra for known concentrations of redistilled natural squalene. It was found that the specific activity of the squalene- $\mathrm{C}^{14}$ was greater than 3 times $10^{6} \mathrm{dpm}$ per $\mathrm{mM}$.

Isolation of fatty acids (Table $V$ ). The nonsaponifiable portion of the alcoholic-aqueous $\mathrm{KOH}$ solution was extracted three times with petroleum ether. The latter was washed with small portions of $2 \mathrm{~N} \mathrm{KOH}$ and then with water, and these were combined with the soap fraction. The alkaline fraction was neutralized and the organic solvents (ethanol and traces of petroleum ether) were evaporated off. The aqueous solution was acidified with sulfuric acid and the resulting turbid suspension was placed in a refrigerator to allow the fatty acids to precipitate. The solution was filtered and the filter paper plus residue was continuously extracted with petroleum ether for 16 hours in a Soxhlet apparatus. Controls using stearic acid showed that more than 90 per cent of this fatty acid could be recovered on a semimicro scale. Aliquots of the resulting solution containing the labeled fatty acids were plated out, using aluminum planchets containing a lens paper disc.

\section{RESULTS}

Oral administration of hydrocarbon fraction containing squalene- $T$ in the human

The specific activity of plasma-free cholesterol following oral administration of the hydrocarbon fraction containing squalene- $T$ at various intervals following administration of the dose is listed in Table II and plotted in Figure 1. The presence of cholesterol labeled with tritium was readily detectable after one hour. The specific activity

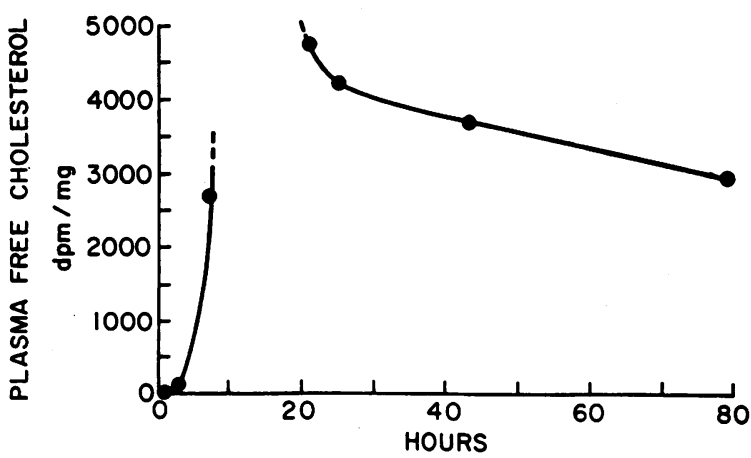

Fig. 1. Specific Activity of Plasma-Free Cholesterol Following Administration in the Human of Hydrocarbon Fraction Containing Squalene-T
TABLE III

Tritium content of liver cholesterol following administration of hydrocarbon fraction containing squalene- $T$ in the mouse

\begin{tabular}{cccc}
\hline \hline & & \multicolumn{2}{c}{$\begin{array}{c}\text { Percentage conversion } \\
\text { based on: }\end{array}$} \\
\cline { 3 - 4 } $\begin{array}{c}\text { Expt. } \\
\text { no. }\end{array}$ & $\begin{array}{c}\text { Sample } \\
\text { administered }\end{array}$ & $\begin{array}{c}\text { Activity as } \\
\text { squalene }\end{array}$ & $\begin{array}{c}\text { Total } \\
\text { activity }\end{array}$ \\
\hline $1^{*}$ & I & 2.1 & 1.1 \\
2 & I & 0.75 & 0.41 \\
3 & I & 0.63 & 0.35 \\
4 & I & 0.90 & 0.49 \\
5 & II & 0.25 & 0.15 \\
6 & II & 0.10 & 0.06 \\
\hline
\end{tabular}

* Administered by intravenous injection of emulsion in saline in Experiment 5; by admixture with food in the other experiments.

reached a maximum in the interval between the 7 and 21 hour points and the curve after 21 hours is roughly comparable to that for plasma-free cholesterol after oral ingestion of the labeled sterol (19). The specific activity of the fatty acids in the blood lipids was measured at 3, 7 and 21 hours (column 3, Table II). At 7 and 21 hours, the fatty acid specific activity was 0.06 and 0.01 of the plasma-free cholesterol, respectively.

\section{Administration of labeled squalene in the mouse}

a) Squalene-T. The liver cholesterol (purified via the dibromide procedure) was assayed. The percentage conversion of squalene to cholesterol in this organ ranged from 0.10 to 2.1 per cent (column 3, Table III).

b) Squalene-C $C^{14}$. Following intravenous injection of the squalene- $\mathrm{C}^{14}$ in the mouse, cholesterol in the liver and remainder of the carcass as well as the respiratory carbon dioxide was assayed for radiocarbon content (Table IV). At the end of five hours, 3.3 per cent of the administered activity was present as liver cholesterol while less than 1 per cent of the radiocarbon administered was present as cholesterol in the remainder of the carcass. Following oral administration (Table V) approximately 1 per cent of the administered radiocarbon was present as cholesterol, mainly in the liver. Relatively small conversion of the radiocarbon in the administered squalene- $\mathrm{C}^{14}$ to respiratory carbon dioxide was found ( 0.5 and 0.2 per cent, respectively) at the time of sacrifice (Tables IV and V). Approximately 1.5 per cent 
TABLE IV

Conversion of squalene- $C^{14}$ to cholesterol and respiratory carbon dioxide in the mouse-Intravenous administration

\begin{tabular}{|c|c|c|}
\hline Compound & Source & $\begin{array}{l}\text { Percentage } \\
\text { of injected } \\
\text { activity }\end{array}$ \\
\hline Cholesterol & $\begin{array}{l}\text { Liver } \\
\text { Remainder of } \\
\text { carcass }\end{array}$ & $<1$ \\
\hline \multirow[t]{3}{*}{ Carbon dioxide } & $\begin{array}{l}\text { Collection interval } \\
\text { of expired air (hrs.) }\end{array}$ & \\
\hline & $\begin{array}{c}0-0.5 \\
0.5-1.0 \\
1.0-1.5 \\
1.5-2.0 \\
2-3 \\
3-4 \\
4-5\end{array}$ & $\begin{array}{l}0.02 \\
0.00 \\
* \\
0.00 \\
0.24 \\
0.15 \\
0.06\end{array}$ \\
\hline & Total & 0.47 \\
\hline
\end{tabular}

* Sample lost during analysis.

of the administered radiocarbon (Table V) was present in the lipid fatty acids. Each mouse in the experiments summarized in Tables IV and V received 8 times $10^{4} \mathrm{dpm}$ radiocarbon contained in less than $11 \mathrm{mg}$. squalene.

\section{DISCUSSION}

The results in the mouse (Table III) served to demonstrate that the squalene- $T$ preparation was a useful precursor material for studies of cholesterol biosynthesis. The oral administration of this precursor in the human (Table II) resulted in a much larger percentage conversion to cholesterol than in the case of the mouse experiments. The extent to which the tritium present in the administered dose was incorporated into cholesterol can be estimated from the circulating cholesterol level together with reasonable assumptions concerning equilibrium of plasma cholesterol with other cholesterol pools. The specific activity at 25 hours was $4.24 \times 10^{3} \mathrm{dpm}$ per mg. cholesterol. The plasma cholesterol level was $176 \mathrm{mg}$. per 100 $\mathrm{ml}$. It can be reasonably assumed (for the purposes of this calculation) that there are: a) $43 \mathrm{ml}$. plasma per $\mathrm{Kg}$. body weight and $b$ ) rapid equilibration of plasma cholesterol with $3 \mathrm{Gm}$. red blood cell free cholesterol, $3.8 \mathrm{Gm}$. free and $0.7 \mathrm{Gm}$. ester cholesterol in the liver (16). Since the total administered radioactivity was $2.67 \times 10^{8} \mathrm{dpm}$, it follows that 24 per cent of the tritium activity
TABLE V

Conversion of squalene- $C^{14}$ to cholesterol, fatty acids and respiratory carbon dioxide in the mouseOral administration

\begin{tabular}{|c|c|c|}
\hline Compound & Source & $\begin{array}{l}\text { Percentage of } \\
\text { administered } \\
\text { activity }\end{array}$ \\
\hline Cholesterol & $\begin{array}{l}\text { Liver } \\
\text { Remainder of } \\
\text { carcass }\end{array}$ & $\begin{array}{l}0.86 \\
0.07\end{array}$ \\
\hline Lipid fatty acids & $\begin{array}{l}\text { Liver } \\
\text { Remainder of } \\
\text { carcass }\end{array}$ & $\begin{array}{c}<0.01 \\
1.5\end{array}$ \\
\hline \multirow[t]{3}{*}{ Carbon dioxide } & $\begin{array}{l}\text { Collection interval } \\
\text { of expired air (hrs.) }\end{array}$ & \\
\hline & $\begin{array}{c}0-0.5 \\
0.5-1 \\
1-2 \\
2-3 \\
3-4 \\
4-5 \\
5-6 \\
6-7\end{array}$ & $\begin{array}{l}0.01_{1} \\
0.02_{2} \\
0.03_{3} \\
0.03_{1} \\
0.03_{1} \\
0.03_{1} \\
0.01_{8} \\
0.02_{1}\end{array}$ \\
\hline & Total & 0.20 \\
\hline
\end{tabular}

was converted to cholesterol. If it is further assumed that only the squalene- $T$ was utilized, this would correspond to a utilization of over 40 per cent of the administered label. When labeled cholesterol was fed to subjects, it was found that about 12 per cent appeared in the plasma (19). The extent of conversion in the case of squalene as precursor is significantly high. This result is direct experimental evidence for the hypothesis that squalene or a closely related compound is an important intermediate in the synthesis of cholesterol by the human. Using absorption data reported in animal experiments and the results of studies in the human, McGuire and Lipsky had estimated that approximately 20 per cent of liver cholesterol was derived from administered (unlabeled) squalene (20).

\section{SUMMARY}

1. A hydrocarbon fraction containing squalene labeled with tritium was prepared by the reaction of squalene with tritium-containing water in the presence of a platinum catalyst. On oral administration of this hydrocarbon fraction in the human. the tritium content of the plasma-free cholesterol reached a maximum within 7 to 21 hours. Calculations based on these data indicated that over 20 per cent of the administered tritium label was con- 
verted to cholesterol tritium. Incorporation of the labeled squalene into the liver cholesterol of mice was also demonstrated. These results furnish direct support for the hypothesis that squalene, or a closely related compound, is an important intermediate in the synthesis of cholesterol by the human.

2. The in vivo synthesis of squalene from acetate precursor was used to prepare squalene- $\mathrm{C}^{14}$ for metabolic studies. On intraperitoneal administration of acetate-2- $\mathrm{C}^{14}$ to a dog, approximately 0.1 per cent of the administered radiocarbon activity was present in the liver squalene after one hour. The labeled squalene was administered to mice and the radiocarbon content of cholesterol, fatty acids, and respiratory carbon dioxide measured. Less than 1 per cent of the administered radiocarbon was eliminated as respiratory carbon dioxide in a seven hour period following administration. After this time, the mouse lipid fatty acids contained less than 2 per cent of the radiocarbon in the administered squalene.

\section{ACK NOWLEDGMENTS}

The authors are indebted to Mrs. T. F. Gallagher and Miss F. Herling for the infra-red analyses of the squalene- $\mathrm{C}^{14}$ and squalene- $\mathrm{T}$ preparations. The cholesterol assays were carried out by the Division of Clinical Biochemistry. Leonard Kotin assisted in the preparation of the adduct of squalene and thiourea. Microanalyses of squalene and its derivatives were carried out by $\mathrm{J}$. Alicino.

\section{REFERENCES}

1. Langdon, R. G., and Bloch, K. The utilization of squalene in the biosynthesis of cholesterol. J. biol. Chem. 1953, 200, 135.

2. Tomkins, G. M., Dauben, W. G., Sheppard, H., and Chaikoff, I. L. Squalene as a precursor of cholesterol in liver. J. biol. Chem. 1953, 202, 487.

3. Schwenk, E., Todd, D., and Fish, C. A. Studies on the biosynthesis of cholesterol. VI. Companions of cholesterol- $\mathrm{C}^{14}$ in liver perfusions, including squalene- $\mathrm{C}^{\mathbf{1 4}}$, as possible precursors in its biosynthesis. Arch. Biochem. 1954, 49, 187.

4. Friedman, M., Byers, S. O., and St. George, S. Cholesterol metabolism. Ann. Rev. Biochem. 1956, 25, 613.

5. Tchen, T. T., and Bloch, K. On the conversion of squalene to lanosterol in vitro. J. biol. Chem. 1957, 226, 921.
6. Eidinoff, M. L., Rosenfeld, R. S., Knoll, J. E., Marano, B. J., and Hellman, L. The biosynthesis of squalene from acetate in man. J. clin. Invest. 1954, 33, 333.

7. Eidinoff, M. L., Knoll, J. E., Fukushima, D. K., and Gallagher, T. F. Equilibrium between protium, deuterium and tritium in the system: hydrogenacetic acid; isotopic fractionation factors in a catalytic hydrogenation. J. Amer. chem. Soc. 1952, 74, 5280.

8. Eidinoff, M. L. Measurement of radiocarbon as carbon dioxide inside Geiger-Müller counters. Analyt. Chem. 1950, 22, 529.

9. Eidinoff, M. L. Measurement of specific disintegration rates by internal gas counting. Analyt. Chem. 1951, 23, 632.

10. Nicolaides, N., and Laves, F. The stereochemistry of squalene. A new method for the determination of cis-trans isomerism. J. Amer. chem. Soc. 1954, 76, 2596.

11. MacKenna, R. M. B., Wheatley, V. R., and Wormall, A. The composition of surface skin fat (sebum) from the human forearm. J. invest. Dermat. 1950, $15,33$.

12. Dauben, W. G., and Bradlow, H. L. The synthesis of $\mathrm{C}^{14}$-labeled "squalene." J. Amer. chem. Soc. 1952, 74, 5204.

13. Tomkins, G. M., Chaikoff, I. L., Dauben, W. G., Bradlow, H. L., and Srere, P. A. Synthetic $\mathrm{C}^{14}$ "squalene"; concerning its incorporation into cholesterol by liver. J. Amer. chem. Soc. 1952, 74, 6145.

14. Schoenheimer, R. Methodik zur quantitativen Trennung von ungesättigten und gesättigten Sterinen. Hoppe-Seylers Z. physiol. Chem. 1930, 192, 77.

15. Schoenheimer, R. The action of iodides on sterol dibromides and the preparation of cholestenone. J. biol. Chem. 1935, 110, 461.

16. Hellman, L., Rosenfeld, R. S., and Gallagher, T. F. Cholesterol synthesis from $\mathrm{C}^{14}$-acetate in man. J. clin. Invest. 1954, 33, 142.

17. Langdon, R. G., and Bloch, K. The biosynthesis of squalene. J. biol. Chem. 1953, 200, 129.

18. Van Slyke, D. D., and Folch, J. Manometric carbon determination. J. biol. Chem. 1940, 136, 509.

19. Hellman, L., Rosenfeld, R. S., Eidinoff, M. L., Fukushima, D. K., Gallagher, T. F., Wang, C., and Adlersberg, D. Isotopic studies of plasma cholesterol of endogenous and exogenous origins. J. clin. Invest. 1955, 34, 48.

20. McGuire, J. S., Jr., and Lipsky, S. R. The effects of squalene on the incorporation of acetate into plasma cholesterol in man. J. clin. Invest. 1955, 34, 704 . 